\title{
Business Model Canvas (BMC): Sebuah Pendekatan Dalam Mendorong Mindset Kewirausahaan
}

\author{
Anaseputri Jamira', Yulita Febriani ${ }^{2}$, Muhammad Amali ${ }^{3}$ \\ Universitas Batanghari ${ }^{1}$, Universitas Batanghari ${ }^{2}$, Universitas Batanghari ${ }^{3}$ \\ email korespondensi: anaseputrijamira24@gmail.com
}

\begin{abstract}
Abstrak: Tujuan dari penelitian ini adalah untuk memahami Business Model Canvas (BMC) dan penerapannya untuk mendorong mindset kewirausahaan mahasiswa. BMC telah menjadi alat analisis yang populer digunakan untuk menganalisis strategi ataupun model bisnis dari suatu unit usaha, perusahaan, atau organisasi. Terdapat gap dari penelitian sebelumnya yang menggunakan penelitian tradisional yang hanya fokus pada pengembangan teori. Penelitian Tindakan (Action Research) memberikan pendekatan yang tepat untuk memperbaiki situasi kerja atau kondisi belajar secara efektif dan efisien. Penelitian ini bersifat kualitatif dan kuantitatif. Ada 84 mahasiswa yang berpartisipasi dalam penelitian ini dengan mengisi kuesioner. Hasil penelitian menunjukkan bahwa metode $B M C$ dapat meningkatkan mindset kewirausahaan mahasiswa. Metode BMC layak untuk diperkenalkan dan diajarkan di dalam Mata Kuliah Kewirausahaan kepada mahasiswa.
\end{abstract}

Kata kunci: Business Model Canvas, Mindset, Kewirausahaan

Kewirausahaan merupakan mindset, skillset dan toolset untuk membuat solusi tepat bagi masyarakat sekitar. Ada begitu banyak definisi kewirausahaan tapi secara umum kewirausahaan dapat didefinisikan sebagai proses mengidentifikasi, mengembangkan dan membawa visi ke dalam kehidupan. Sederhananya, kewirausahaan merupakan proses penciptaan lapangan kerja bagi dirinya sendiri.

Makna dari kewirausahaan tidak terbatas hanya pada bisnis, karena bisnis tidak selalu memberikan perubahan positif bagi orang lain. Oleh karena itu, pemberian manfaat bagi orang lain yang menjadi penekanan dalam kewirausahaan, bukan hanya soal untung rugi.

Pemahaman makna dapat terlihat dari perilaku individu seperti caranya melihat permasalahan, mengambil keputusan, dan menyelesaikan masalah tersebut. Sehingga, tidak mengherankan jika dikatakan wirausaha dalam konteks yang lebih luas dapat memperkuat tatanan perekonomian suatu negara melalui sumbangsihnya terhadap pembangunan ekonomi, pemberdayaan dan peningkatan kualitas sumber daya, penciptaan lapangan kerja, serta mewujudkan terciptanya pemerataan kesejahteraaan ekonomi dan sosial.

Indonesia sendiri masih kekurangan banyak wirausaha jika dibandingkan dengan negara maju lainnya. Padahal, masyarakat Indonesia menganggap kewirausahaan sebagai pilihan karir yang menarik. Faktor turunnya keinginan menjadi wirausaha disebabkan masyarakat belum memahami makna kewirausahaan yang tidak melulu soal untung rugi.

Mengatasi hal tersebut, pemerintah terus berupaya untuk meningkatkan jumlah wirausaha dengan menyisipkan pemahaman 
mengenai kewirausahaan ke dalam kurikulum perguruan tinggi. Bahkan menjadi salah satu indikator pemeringkatan Perguruan Tinggi. (Kemenristekdikti, LLDIKTI Wil. X, 2019).

Salah satu metode dasar perancangan ide dan proposal bisnis adalah dengan metode Business Model Canvas (BMC). Metode ini merupakan alat analisis model bisnis dengan penyajian data secara sederhana namun menyeluruh terhadap sembilan komponen esensial pada bisnis.

Metode ini begitu populer dan banyak digunakan dalam berbagai studi kasus penelitian (Hermawan, 2020; Indah, 2020; Kamaluddin, 2020; Agusty, 2020; Nurhayat, 2020; Ojasalo and Ojasalo, 2018; Ruspriono, 2020; Siburian, 2020; Tirtayasa, 2020; Victor, 2020). Meskipun sederhana, BMC dapat membantu tahap awal validasi ide bisnis pada tahap perencanaan agar lebih matang dan siap dijalankan.

Model bisnis kanvas digambarkan melalui sembilan blok bangunan dasar yang menunjukkan logika bagaimana sebuah perusahaan bermaksud untuk menghasilkan uang.

Sembilan blok ini mencakup empat bidang utama bisnis yaitu pelanggan, penawaran, infrastruktur, dan kelayakan keuangan.

Dalam buku berjudul "The Startup Owner's Manual: The Step-byStep Guide for Building a Great Company" yang ditulis oleh Steve Blank dan Bob Dorf (2012) dijelaskan ke sembilan elemen dalam model bisnis kanvas (customer segment, value propositions, channels, customer relationships, revenue streams, key resources, key activities, key partners, dan cost structure).

Customer segment, pertama-tama organisasi harus menetapkan siapa yang harus dilayani. Organisasi dapat menetapkan untuk melayani satu atau lebih segmen.

Value propositions adalah manfaat atau nilai yang ditawarkan perusahaan kepada segmen pasar yang dilayani. Penawaran nilai ini juga yang menjadi alasan kenapa pelanggan harus membeli produk/jasa yang ditawarkan.

Channels adalah saluran untuk berhubungan dengan para pelanggan dimana merupakan sarana bagi perusahaan untuk menyampaikan Value Proposition kepada Customer Segment yang dilayani.

Customer relationships adalah cara bagaimana perusahaan menjalin hubungan baik dengan pelanggannya. Revenue streams adalah pemasukan yang biasanya diukur dalam bentuk uang yang diterima perusahaan dari pelanggannya.

Key resources merupakan sumber daya utama yang harus dimiliki perusahaan untuk menjalankan bisnis, yang berupa sumber daya manusia, teknologi, finansial, dan sumber daya fisik. Key activities merupakan aktifitas utama yang harus dikuasai perusahaan untuk menjalankan bisnis. 
Key partner merupakan sumber daya yang diperlukan oleh perusahaan untuk mewujudkan proposisi nilai, tetapi tidak dimiliki oleh perusahaan tersebut. Cost Structure menjelaskan mengenai strukturstruktur biaya yang terlibat dalam bisnis, baik itu fixed dan variable cost.

Adi W. Gunawan (2008) dalam bukunya The Secret of Mindset, menjelaskan bahwa mindset terdiri dari dua kata, yaitu Mind dan Set. Mind artinya adalah pemikiran, atau biasa disebut sebagai sumber kesadaran yang dapat menghasilkan pikiran, ide, perasaan dan persepsi, dan dapat menyimpan memori dan pengetahuan. Set adalah keadaan utuh atau mendahulukan peningkatan kemampuan dalam suatu kegiatan.

Mindset merupakan sekumpulan kepercayaan dan cara berpikir yang dapat menentukan pandangan, perilaku, sikap dan juga masa depan seseorang.

Menurut Ita Athia, Ety Saraswati, dan Andi Normaladewi (2018) bahwa Mindset Kewirausahaan dapat dilihat dari 5 faktor yaitu dari seberapa besar minat pada wirausaha, pengetahuan yang dimiliki tentang komponen usaha, pengetahuan tentang cara memulai usaha, keberanian menciptakan usaha, dan kemampuan berkreasi dan berinovasi.

Hal inilah yang mendasari dilaksanakannya Penelitian mengenai Penerapan Business Model Canvas untuk mendorong mindset kewirausahaan dikalangan mahasiswa, khususnya Mahasiswa Fakultas Ekonomi Universitas Batanghari Tahun 2019/2020.

Hal ini didorong pemikiran bahwa masih rendahnya minat mahasiswa untuk berwirausaha, salah satunya ditandai dengan rendahnya tingkat partisipasi mahasiswa yang mengikuti ajang kompetisi kewirausahaan khususnya mahasiswa Fakultas Ekonomi yang telah mempelajari mata kuliah kewirausahaan.

Oleh karena itu permasalahan yang diteliti dalam penelitian ini adalah bagaimana penerapan BMC untuk mendorong mindset kewirausahaan dikalangan mahasiswa Fakultas Ekonomi Universitas Batanghari Tahun 2019/2020?

Adapun tujuan dalam penelitian ini adalah untuk mengetahui penerapan BMC untuk mendorong mindset kewirausahaan dikalangan mahasiswa Fakultas Ekonomi Universitas Batanghari Tahun 2019/2020.

Manfaat penelitian ini untuk mendorong tumbuhnya wirausaha atau calon wirausaha muda yang mumpuni dalam melakukan perencanaan bisnis secara matang, serta mendorong dan mendukung pengembangan pembelajaran kewirausahaan dan peningkatan minat kewirausahaan di Perguruan Tinggi khususnya.

\section{METODE}

Penelitian ini bersifat kualitatif dan kuantitatif. Kedua analisis tersebut digunakan secara bersamaan (Prof.Sugiono, 2006). Pada tahap awal dilakukan survei untuk mengetahui kondisi awal mindset kewirausahaan mahasiswa Fakultas Ekonomi Universitas Batanghari, dengan menggunakan instrumen kuesioner untuk mengetahui seberapa 
besar minat mahasiswa untuk berwirausaha, pengetahuan tentang komponen usaha dan cara memulai usaha, keberanian menciptakan usaha, serta kemampuan berkreasi dan berinovasi.

Penelitian terdahulu oleh Ita Athia, Ety Saraswati, dan Andi Normaladewi (2018) menggunakan metode penelitian yang bersifat kepustakaan dimana mempelajari topik yang menarik atau merupakan penelitian tradisional yang hasil penelitiannya sebatas hanya untuk pengembangan teori. Hal ini dirasa kurang tepat, mengingat penelitian menitikberatkan pada aspek penerapannya.

Adanya Gap dari Penelitian terdahulu, melatarbelakangi penggunaan Metode Penelitian Tindakan. Metode Penelitian Tindakan (Action Research) yang dikenal juga dengan istilah Participatory Research, Collaborative Inquiry, Emancipatory Research, Action Learning, and Contextual Action Reseach, menurut Sugiyono (2015), adalah suatu pendekatan penelitian dengan dua tujuan (ganda), yaitu mengambil tindakan baru yang efektif dan efisien untuk memperbaiki situasi kerja (take action) dan untuk mengembangkan ilmu/ pengetahuan atau teori tentang tindakan (science of action). Jika pada penelitian tradisional hanya satu, berfokus pada pengembangan teori.

Penelitian tindakan merupakan penelitian praktis. Jadi tindakan yang dipilih telah dibuktikan melalui penelitian. Penelitian tindakan digunakan untuk menemukan pengetahuan tentang bagaimana melakukan perbaikan.

Terdapat Empat Level/ Desain dalam penelitian tindakan. Penelitian tindakan Level 1, adalah penelitian tindakan dimana peneliti melakukan penelitian untuk mengetahui potensi dan masalah, dan selanjutnya peneliti memberi saran tindakan, tetapi tidak menguji tindakan tersebut. Penelitian tindakan Level 2, adalah penelitian tindakan dimana peneliti tidak melakukan penelitian untuk mengetahui potensi dan masalah (hanya melakukan refleksi), tetapi langsung menguji rencana tindakan yang diyakini dapat memecahkan masalah atau meningkatkan kinerja. Penelitian tindakan Level 3, adalah penelitian tindakan dimana peneliti melakukan penelitian untuk menemukan masalah dan potensi, dan selanjutnya peneliti mengembangkan tindakan yang telah ada dan menguji tindakan tersebut. Penelitian tindakan Level 4, adalah penelitian tindakan dimana peneliti melakukan penelitian untuk menemukan masalah dan potensi, dan selanjutnya peneliti menemukan atau menciptakan tindakan baru dan menguji tindakan tersebut. Dari segi keilmuan dan metodologi, penelitian tindakan yang tertinggi tingkatannya adalah penelitian tindakan Level 4.

Penelitian yang akan dilakukan oleh Peneliti adalah Penelitian Tindakan Level 2, karena masalah penelitian sudah diketahui, yaitu kurangnya minat mahasiswa dalam berwirausaha, bagaimana usaha untuk mendorong mindset kewirausahaan mahasiswa, dengan suatu metode/ teori yang telah teruji yaitu BMC, jadi hanya melakukan refleksi. 
Sampel melibatkan sebanyak 84 mahasiswa dengan metode kuota sampling, yang merupakan teknik sampling non probability. Dimana teknik ini menentukan sampel dari populasi yang mempunyai ciri-ciri ketentuan sampai jumlah (kuota) yang diinginkan (Sugiyono, 2019). Alasan teknik sampling ini dipilih untuk memenuhi standar protokol kesehatan yang ketat dalam menghadapi Covid-19.

Selanjutnya dilakukan tahap pengenalan penerapan BMC di dalam kelas dan ditugasi untuk merencanakan ide bisnis, selama tiga kali pertemuan, dua sesi tatap muka, satu sesi video conference. Teknik pengumpulan data dengan observasi dan dokumentasi.

Instrumen penelitian yang digunakan berupa angket penilaian mindset kewirausahaan yang diisi oleh mahasiswa dengan menggunakan skala likert dengan tingkatan 1-4 terhadap lima aspek mindset kewirausahaan, yaitu seberapa besar minat pada wirausaha, pengetahuan yang dimiliki tentang komponen usaha, pengetahuan tentang cara memulai usaha, keberanian menciptakan usaha, dan kemampuan berkreasi dan berinovasi. Dimana arti angka $4=$ Sangat Tinggi (ST), 3 = Tinggi (T), 2 = Cukup (C), dan 1 = Rendah (R).

\section{HASIL}

Sebelum pemberian materi BMC, pada tahap awal dilakukan survei untuk mengetahui kondisi mindset awal kewirausahaan terhadap 84 sampel. Tabel 1 menunjukkan bahwa mindset kewirausahaan mahasiswa sebelum penerapan Metode BMC sebanyak 42 orang (50\%) termasuk dalam kategori rendah, 16 orang $(19,05 \%)$ termasuk dalam kategori cukup, 21 orang (25\%) termasuk dalam kategori tinggi, dan 5 orang $(5,95 \%)$ termasuk dalam kategori sangat tinggi. Tampak bahwa sebagian besar mindset kewirausahaan mahasiswa masih termasuk dalam kategori rendah.

Table 1. Pengamatan Mindset Kewirausahaan Mahasiswa Sebelum Pemberian Materi BMC

\begin{tabular}{|c|c|c|c|}
\hline No. & Keterangan & Frekuensi & $\begin{array}{c}\text { Persentase } \\
(\%)\end{array}$ \\
\hline 1 & $\begin{array}{l}\text { Sangat } \\
\text { Tinggi }\end{array}$ & 5 & 5,95 \\
\hline 2 & Tinggi & 21 & 25 \\
\hline 3 & Cukup & 16 & 19,05 \\
\hline \multirow[t]{2}{*}{4} & Rendah & 42 & 50 \\
\hline & Total & 84 & 100 \\
\hline
\end{tabular}

Sumber: Olah Data Peneliti 
Pada tahap pemberian materi BMC, dijelaskan proses BMC dengan memberikan contoh simulasi nyata dalam praktek penggunaannya untuk memunculkan ide bisnis.

Pada tahapan ini menjelaskan langkah-langkah, yang dimulai dari memunculkan ide, melakukan design, tahapan pengujian, proses pivot, dan yang terakhir menceritakan pengalaman.

Bagaimana memunculkan ide, ide bisa datang dari permasalahan. Maka hal yang dilakukan adalah melakukan diskusi dengan beberapa warga masyarakat Jambi baik secara langsung maupun via internet dan pengamatan yang dilakukan untuk menemukan permasalahan yang ada di lingkungan sekitar.

Ada beberapa permasalahan yang diperoleh, yaitu minimnya tempat tujuan wisata dan hiburan di Kota Jambi, kurangnya ketertarikan masyarakat Kota Jambi terhadap seni dan budaya Jambi, kurangnya kepedulian masyarakat Jambi terhadap kelestarian alam di Jambi, seperti Sungai Batanghari dan Danau Sipin, belum adanya tempat diskusi/belajar/sharing ilmu pengetahuan dan informasi yang dapat diakses 24 jam di Jambi.

Berdasarkan asumsi, maka solusi yang ditawarkan yaitu Kapal Pesiar (Tempat tujuan wisata berskala internasional, lengkap, mewah dan ekslusif yang berlayar di atas Sungai Batanghari).

Design dengan ide awal sebuah kapal pesiar dengan konsep yaitu bernuansa budaya Melayu Jambi (sebagai Melayu Tertua di dunia); didominasi warna emas; pertunjukan-pertunjukan budaya melayu; pusat kota dan perbelanjaan dalam pesiar bernuansa Melayu Jambi, convention center, sport center, beauty center, learning center, dsb; kapal berlayar dan singgah di kampung - kampung wisata sepanjang Sungai Batanghari, situs bersejarah Candi Muaro Jambi, Pulau Berhala, hingga ke Malaka; sebagai pusat jajanan dan kuliner Jambi dan nasional terlengkap serta menawarkan kuliner dunia.

Gambaran nyata penjelasan dengan metode BMC Awal Kapal Pesiar dipaparkan secara jelas pada layar yang menggambarkan keseluruhan 9 komponen BMC terkait Ide Kapal Pesiar.

Setelah merancang BMC "kapal pesiar", dilakukan pengujian. Pengujiannya dilakukan dengn cara melakukan bincang dengan Ahli dan meminta masukan; melakukan survei ke Pelabuhan, Jalur Pelayaran, Jembatan Aur Duri I dan Jembatan Aur Duri II; melakukan wawancara langsung dengan beberapa orang calon konsumen; melakukan diskusi dengan beberapa orang warga Jambi; mencari data-data sekunder yang mendukung; dan yang terakhir melakukan survei kecil melalui Sosial Media.

Setelah survei lapangan seperti mengunjungi pelabuhan talang duku di provinsi Jambi yang lokasinya tidak jauh dari pusat kota, Jalur Pelayaran yaitu Sungai Batanghari, Jembatan Aur Duri I dan Jembatan Aur Duri II. Diperoleh gambaran tentang salah satu mega proyek icon provinsi Jambi yaitu Menara Gentala Arasy dan Jembatan Gantung. 
Jembatan gantung ini dibangun persis di depan rumah dinas Gubernur Jambi yang akan menghubungkan dengan wilayah Seberang kota Jambi.

Selanjutnya dilakukan diskusi dengan warga Jambi yaitu Nasir dan Heri, yang merupakan anggota Tim Kesenian Jambi. Mereka memberikan tanggapan bahwa konsepnya bagus tapi mengapa tidak mengangkat kapal kincir dari Jambi sebagai bentuk kapalnya .

Ditemukan juga beberapa fakta yaitu lokasi Pelabuhan Talang Duku Jambi yang berjarak $\pm 10 \mathrm{~km}$ dari Pusat Kota; Pelabuhan Talang Duku hanya dapat disinggahi kapal-kapal kecil; lokasi dok Kapal yang juga berada di daerah Talang Duku; kondisi Jalur Pelayaran Sungai Batanghari mengalami sedimentasi (pendangkalan), terutama aliran ke hulu; percepatan pembangunan pelabuhan Internasional oleh Pemerintah di Sabak yang letaknya starategis, berhadapan langsung dengan Selat Malaka dan Segi Tiga Pusat Pertumbuhan (Singapura, Malaysia dan Batam).

Fakta lainya yang ditemukan adalah Kapal Pesiar minimal bobot 1000 ton; kapal pesiar dapat berlayar di kedalaman minimal 12 meter; Sungai Batanghari rata-rata dalam keadaan normal mencapai kedalaman 8-10 meter; saat pasang dapat mencapai 12 meter sedangkan saat surut hanya mencapai 3,8 meter; bobot maksimal kapal yang berlayar di atas sungai Batanghari maksimal 500 ton; program pengerukan untuk kedalaman sungai Batanghari yang dilakukan pemerintah belum dapat terealisasikan dalam waktu dekat ini.

Langkah selanjutnya adalah privot, berdasarkan fakta yang ditemukan dari hasil pengamatan di lapangan, diskusi, wawancara serta perolehan data sekunder yang dilakukan maka dapat disimpulkan bahwa tempat tujuan wisata kapal pesiar belum dapat direalisasikan. akan tetapi, tidak menutup kemungkinan tujuan wisata air dalam bentuk lain. Maka diangkat ide untuk membuat restoran terapung yang mengangkat nuansa kapal tradisional jambi.

Setelah Pivot, dipaparkan kembali BMC yang telah direvisi idenya menjadi Restoran Terapung Kapal Tradisional Jambi.

Terakhir, peserta diminta menceritakan apa yang didapatkannya melalui metode BMC.

Setelah pemberian materi BMC selesai dilakukan, dapat dilihat berdasarkan Tabel 2, jumlah mahasiswa yang memiliki mindset kewirausahaan yang tinggi dan sangat tinggi mencapai $60,71 \%$, lebih banyak dibandingkan dengan mahasiswa yang memiliki mindset kewirausahaan yang cukup rendah dan rendah yaitu sebesar 39,29\%. 
Table 2. Pengamatan Mindset Kewirausahaan Mahasiswa Sesudah Pemberian Materi BMC

\begin{tabular}{|c|c|c|c|}
\hline No. & Keterangan & Frekuensi & $\begin{array}{c}\text { Persentase } \\
(\%)\end{array}$ \\
\hline 1 & $\begin{array}{c}\text { Sangat } \\
\text { Tinggi }\end{array}$ & 21 & 25 \\
\hline 2 & Tinggi & 30 & 35,71 \\
\hline 3 & Cukup & 27 & 32,14 \\
\hline \multirow[t]{2}{*}{4} & Rendah & 6 & 7,15 \\
\hline & Total & 84 & 100 \\
\hline
\end{tabular}

Sumber: Olah Data Peneliti

Sebelum penerapan Metode BMC, persentase mahasiswa yang memiliki mindset kewirausahaan yang tinggi hanya berjumlah 26 orang atau sebesar 30,95 \%. Kemudian, setelah dilakukan penerapan Metode BMC, persentase mahasiswa yang memiliki mindset kewirausahaan yang tinggi meningkat menjadi 51 orang atau sebesar 60,71\%.

Ruang lingkup penelitian ini kecil, terbatas hanya pada satu Fakultas dari sebuah Perguruan Tinggi, kedepannya ruang lingkup penelitian dapat diperluas sampai tingkat Nasional.

\section{KESIMPULAN}

Hasil penelitian menunjukkan bahwa Metode BMC dapat meningkatkan mindset kewirausahaan pada Mahasiswa Fakultas Ekonomi Universitas Batanghari. Metode BMC layak untuk diperkenalkan dan diajarkan kepada mahasiswa dalam mata kuliah kewirausahaan.

Mahasiswa memiliki pemahaman yang baik terhadap pengetahuan tentang bagaimana memulai usaha, serta memiliki keberanian, kemampuan berkreasi, dan berinovasi serta minat yang tinggi untuk memulai usaha.

\section{DAFTAR PUSTAKA}

Agusty, Rosana Mia. (2020). Designing Business Model Canvas Transforms Into Balanced Scorecard in the $X Y Z$ University in Indonesia. Dinasti International Journal of Management Science. 1, 6 (Jul. 2020), 830-843. https://doi.org/10.31933/dijms.v1i6.392

Athia, Ita, Saraswati, Ety, and Normaladewi, Andi. (2018). Penerapan Business Model Canvas (BMC) untuk Mendorong Mindset Kewirausahaan di Kalangan Mahasiswa Universitas Islam Malang. Jurnal Ketahanan Pangan, 2(1), 66-75. http://riset.unisma.ac.id/index.php/JU-ke/article/view/1051/1086

Blank, Steve, and Dorf, Bob. (2012). The Startup Owner's Manual: The Step-by-Step Guide for Building a Great Company. United State of America: K\&S Ranch.

Gunawan, Adi W. (2008). The Secret of Mindset. Jakarta: Gramedia 
Pustaka Utama.

Hermawan, Frendy. (2020). Analysis of Family Business Development Model Based on Business Model Canvas (Case Study in CV. MXY). Dinasti International Journal of Digital Business Management, 1(5), 829-841. https://dinastipub.org/DIJDBM/article/view/486

Indah, RA. lis Suci Nur. (2020). Planning Business Model Canvas with SWOT Method at $X Y Z$ Institute. Dinasti International Journal of Digital Business Management, 1(5) 781-793. https://dinastipub.org/DIJDBM/article/view/483

Kamaluddin, Iqbal. (2020). Business Development Strategy with Canvas Model Business Approach in CV. Hakhenbik. Dinasti International Journal of Economic, Finance, and Accounting, 1(3), 469-481. https://doi.org/10.38035/dijefa.v1i3.431

Kemenristekdikti, LLDIKTI Wil. X. (2019). Panduan Entrepreneurship Award III-2019. Unpublished. Padang: LLDIKTI Wil. X.

Nurhayat, Kartika. (2020). Designing Business Canvas Model and Analysis Business in Warung Dimsum. Dinasti International Journal of Management Science, 1(6), 903-912. https://doi.org/10.31933/dijms.v1i6.398

Ojasalo, Jukka, and Ojasalo, Katri. (2018). Service Logic Business Model Canvas. Journal of Research in Marketing and Entrepreneurship: Emerald Publishing Limited, 20(1), 1471-5201. https://www.researchgate.net/publication/338300234 Service Logi $\mathrm{c}$ Business Model Canvas for Lean Development of SMEs an d Start-Ups

Ruspriono. (2020). Business Analysis Model Using Canvas Business Model Approach to KJPP Yanuar Bey and Partners. Dinasti International Journal of Digital Business Management, 1(4) 608-617. https://dinastipub.org/DIJDBM/article/view/370

Siburian, Agus Mangiring. (2020). Implementation of Business Model Canvas in Chemical Manufacturing Company PT. Timuraya Tunggal. Dinasti International Journal of Economic, Finance, and Accounting, $1(3)$, 421-430. https://dinastipub.org/DIJEFA/article/view/421

Sugiyono. (2006). Metode Penelitian Pendidikan (Pendekatan Kuantitatif, Kualitatif, dan R \& D). Bandung: Alfabeta.

Sugiyono. (2015). Metode Penelitian Tindakan Komprehensif. Bandung: Alfabeta.

Sugiyono. (2019). Metode Penelitian Pendidikan. Bandung: Alfabeta.

Tirtayasa, Yohan. (2020). Canvas Business Strategy in the Aapplication of Local Credits in Bank BCA. Dinasti International Journal of Management Science, 1(6), 854-862. https://doi.org/10.31933/dijms.v1i6.394

Victor. (2020). Business Analysis of Canvas and SWOT Models (Case Study for Culinary Crossbreed Cake "Tn. Xyz"). Dinasti International Journal of Economic, Finance, and Accounting, 1(3), 
PROSIDING SEMINAR NASIONAL EKONOMI DAN BISNIS 2021 UNIVERSITAS MUHAMMADIYAH JEMBER

515-525. https://dinastipub.org/DIJEFA/article/view/451 